Article

\title{
Can the Pandemic Be a Catalyst of Spatial Changes Leading Towards the Smart City?
}

\author{
Barbara Zgórska *, Dorota Kamrowska-Załuska and Piotr Lorens \\ Faculty of Architecture, Gdańsk University of Technology, Poland; E-Mails: barbara.zgorska@pg.edu.pl (B.Z.), \\ dzaluska@pg.edu.pl (D.K.-Z.), plorens@pg.edu.pl (P.L.) \\ * Corresponding author
}

Submitted: 7 May 2021 | Accepted: 13 August 2021 | Published: 17 November 2021

\begin{abstract}
The worldwide spread of Covid-19 infections has had a pervasive influence on cities and the lives of their residents. The current crisis has highlighted many urban problems, including those related to the functionality of urban structures, which directly affect the quality of life. Concurrently, the notion of "smart cities" is becoming a dominant trend in the discourse on urban development. At the intersection of these two phenomena, questions about the effects of Covid-19 on the future of cities arise. These are concerned with the possible roles of the pandemic in the process of urban regeneration and the development of smart solutions. The article aims to create a conceptual framework that will allow researchers to assess the influence of Covid-19-related changes on urban structures and their functionality in the following areas: city structure, connectivity and mobility, public spaces, access to green areas, and digital transformation. In the empirical part of the article, the influence of pandemic-caused changes on the development of various aspects of smart cities is discussed. The article concludes with an analysis of the effects the pandemic might have on digital urban regeneration.
\end{abstract}

\section{Keywords}

Covid-19; smart city; urban change

\section{Issue}

This article is part of the issue "Towards Digital Urban Regeneration: Embedding Digital Technologies Into Urban Renewal Processes and Development" edited by Dalit Shach-Pinsly (Technion-Israel Institute of Technology, Israel).

(C) 2021 by the authors; licensee Cogitatio (Lisbon, Portugal). This article is licensed under a Creative Commons Attribution 4.0 International License (CC BY).

\section{Introduction}

The coronavirus disease (Covid-19) is considered to have a pervasive influence on people living in cities. But one must note that hazardous situations and extreme challenges have shaped cities/urban organisms since the beginning of times. Plagues, wars, political changes, or even abrupt economic transformations have led to new ideas in city development (British History Online, 2019; Naphy \& Spicer, 2004). For instance, in 17th-century London, which at the time had about half a million inhabitants, in the face of the plague of 1663-1665 and the Great Fire of 1666, a new law was adopted. It regulated the principles of the city's reconstruction, taking into account higher fire resistance of buildings, and the creation of wider streets and pavements (British History Online, 2019). After the cholera epidemic in the 19 th century, a sewage system was implemented in Paris and London by separating waste from drinking water, thus identifying the sanitary (and metaphysical) need to maintain cleanliness (Naphy \& Spicer, 2004). Relatively recent pandemics (e.g., smallpox, SARS, swine flu) led to the development of mathematical solutions connected with the mobility of people and social networks, allowing the control of infectious diseases. Those analyses contributed to a better understanding of the dynamics, transmission mechanisms, and spatial correlations of diseases that can help administrative authorities in crisis management (Eubank et al., 2004; Keeling, 1999; Parimala \& Lopez, 2016). 
Changes brought about by the Covid-19 pandemic can be considered as a test bed for the functionality of urban structures, underlining the already existing urban problems. Thus, the question is whether the pandemic, as it is opening a new perspective on the functioning of cities and the quality of their residents' lives (Dietz et al., 2020), can be a catalyst of change. The pandemic increased the acceptance of digital transformation (Nicola et al., 2020), which is at the core of the notion of smart cities and starts to be seen as one of the pillars of future urban development (Chourabi et al., 2012; Neirotti et al., 2014). Although initially focused mainly on information technology, currently the transformation encompasses institutional and social elements related to technologies facilitating the transformation of the economy, environment, and community (Berry \& Glaeser, 2005; Coe et al., 2001). Will the pandemic further change the concept of a smart city, bringing it closer to the notion of resilience and defining it as a city that is resistant to both pandemic crises and responsive to the challenges of the climate change?

Smart solutions and strategies deeply influence the spatial configuration and functioning of urban areas (Caragliu et al., 2011). Information society strongly shapes the environment we live in and influences relations within the society as well as the urban flow of materials, people, and goods. The use of big data creates new design opportunities for cities, allowing them to create better services, and more effectively address residents' needs. It also supports agile adaptation to changes. To examine how those two phenomena influence the future planning of cities, it seems sensible to ask: Will the pandemic produce significant changes in shaping the cities of the future? May it be a catalyst of urban change? If so, what kind of transition will urban areas face because of these new phenomena? What role can smart solutions play in that change?

\section{Background: Influence of the Covid-19 Pandemic on Cities and Their Smartness}

In this article, we aim to analyse the impact caused by the Covid-19 pandemic in the following areas: (a) city structure, including polycentricity; (b) mobility and public transportation; (c) shape and functions of public spaces; (d) access to open spaces and green areas; and (e) digital transformation. We have selected these aspects in an analysis of current trends in city transformations, bearing in mind their sustainable development and urban renewal in the post-pandemic future. These aspects are, at the same time, influenced by the idea of a smart city and the Covid-19 pandemic-related changes. These basic aspects of the functioning of cities are identified, among others, by Bereitschaft and Scheller (2020; see also Florida, 2020). In the empirical part, we analyse how changes in these aspects relate to various components of the "smart city" (smart governance, smart economy, smart mobility, smart environment, smart people, and smart living) using the proposed assessment framework. To discuss the most relevant connections and relationships, we relate both blocks of issues to each other based on the proposed qualitative assessment framework.

\subsection{City Transformation Trends Strengthened by the Covid-19 Pandemic}

The city structure concerns general relations between various areas. Specific attention is paid to the workplaceschool-residence relationship as the most frequent transportation route for city dwellers. Changes in workplace distribution, managing public facilities and spaces are currently vital, too, in the development of spatial policies. Computer modelling allows municipalities to investigate the relationships between travel destinations and the choice of a means of transport (Frank, 1994), as well as the behaviours related to commuting to work (Smith \& Zenou, 2003), or the relationship between the spatial structure and resilience of cities (Yuwen et al., 2020). In global travel destinations, the suspension of tourist traffic resulted in the emptying of city centres, highlighting the historical importance of overtourism and its impact on residents, the local economy, the preservation of public spaces, and the destination's capacity.

Mobility and public transportation refer to balancing and reducing the dependence of residents on the car, promoting public transport and planning transport in the spirit of the idea of the smart city (Diao, 2019; Nakamura \& Hayashi, 2013). The city is developed to allow access to primary services on foot-following the idea of chronourbanism (Gwiazdzinski, 2015) and the 15-minute city (de Valderrama et al., 2020; Graells-Garrido et al., 2021), or even a five-minute city (Maas, 2003). In light of these trends, citizens who experience remote work or distance learning gather new habits about city mobility and space accessibility and functionality around their place of residence.

The shape and function of public spaces are considered as important elements of the visual perception, comfort, and safeness in the cities. Increasing the possibilities of exploration and reorganising towards greater accessibility also for excluded groups (Gehl, 2007) is one of the current trends in the transformation of public spaces (Stevens, 2007). Limiting individual car use during the most severe restrictions, while introducing the obligation to maintain physical distance, changed the way streets and pavements have been used in cities, which is in line with the current trends of increasing the functionality, accessibility, and quality of public spaces.

Access to open spaces and green areas is an element of urban policies developed in cities in the spirit of the idea of environmental justice as well as the quality of green space concerning the cultural needs of a given community (Kabisch \& Haase, 2014), aimed at improving access to green areas (Fuller \& Gaston, 2009). Increasing the availability of green areas in cities improves their resistance to climate change. During the 
Covid-19 pandemic, our attention was drawn not only to parks and city squares but also to places that had not been explored, such as the so-called urban wasteland, degraded areas, and even rooftops that can be adopted for recreational purposes (Honey-Rosés et al., in press).

Digital transformation acceleration caused by the pandemic tends to be one of its most significant longlasting effects, indirectly influencing changes leading to the development of the smart city (Soto-Acosta, 2020). The crisis has shown the potential of digital technologies. The Covid-19 pandemic has also caused ubiquitous technologies embedded in the public realm to gain higher public acceptance. The implementation of innovations in a remote form will be a permanent effect with a significant impact on relations between city residents (Hantrais et al., 2020). It may also support post-pandemic digital urban regeneration.

\subsection{Smartness Embedded in City Structures}

Although smart city assessment frameworks originally focused on information technologies, currently, all the analysed smart city models stress the importance of institutional and social elements related to technology that can support the transformation of the cities, their economy, environment, and community (Berry \& Glaeser, 2005; Coe et al., 2001). Those assessment frameworks developed from a technology-oriented approach into a holistic framework, allowing for the evaluation of all aspects of smart urban space. Although in recent years various new smart city assessment frameworks have been introduced, both on the functional level of city development (ITU-T Focus Group on Smart Sustainable Cities, 2015; UNECE Committee on Housing and Land Management, 2015) as well as on the assessment of the spatial dimension of smart cities (Komninos, 2011), we would like to argue that the classical framework proposed by Griffinger et al. (2007) and further developed by Cohen (2014) still allows for a comprehensive evaluation of all aspects of smart urban development. Thus, for our analytical model based on the work of Griffinger et al. (2007), we have defined six distinct dimensions of smart development. With already existing studies anchored in Griffinger et al. (2007) and Cohen's (2014) respective studies based on the ecosystem approach (Coca-Stefaniak, 2019), as well as case study analyses (Boes et al., 2016), the chosen framework allows the analysis of smartness through the lens of Covid-19 impact on city transformation trends concerning cities' urban tissue, flows, public spaces, open and green areas, as well as digital layer.

Murgante and Borruso (2015) stress the need to combine the concept of the smart city with the essence of the city itself and with its structural problems. At the same time, as the majority of smart city assessment frameworks focus either on the macro scale of entire city organisms (Angelidou, 2014; International Organization for Standardization, 2014; Kourtit \& Nijkamp, 2013) or directly on the assessment of single projects (Bosch et al., 2017; Monzon, 2015), in our framework, we decided to focus on the mesoscale, trying to get into more finegrain analyses of urban structures. The second aspect of our assessment framework is to include technological issues in the planning framework, with special attention paid to social impact. Smart solutions can only help to solve structural problems of the cities if they simultaneously answer societal needs while being embedded into urban systems. For instance, if a city has a structural mobility problem, it is quite impossible to solve it only with GPS and internet accessibility. This approach formed the basis for a study of how Covid-19-imposed changes impact conceptual components of the smart city. Based on the above-mentioned criteria, the conceptual components of the smart city (see Griffinger et al., 2007) identified in this study are the following:

- Smart Governance (participation): Supports cocreation and participation in decision-making; it is also the factor that enables the use of available technology through transparent, multilevel governance and collaborations with other municipalities and stakeholders to meet citizens' needs and to improve public services.

- Smart Economy (competitiveness): An urban economy where the sector gathers innovation and productivity to adapt to the market's and workers' needs, to enhance the sharing economy, open business models, and use of smart procurements, leading to a resilient global model for both local and global market competition.

- Smart Mobility (transport and ICT): It is expected to offer innovative, clean, equitable, and safe transport systems for people, goods, and data by using available technologies to gather and provide information to users, planners, and transport managers.

- Smart Environment (quality of life): It uses data on utility networks, users, and other city resources (air, water) to establish the main areas of activity in urban and city infrastructure planning, as well as to support urban service managers in achieving sustainable environment and to improve citizens' quality of life.

- Smart People (social and human capital): It empowers citizens to participate in decision making and smart urban life, helping them to adapt to new solutions by providing creativity, innovation, and diversity to their communities; it also focuses on education, which appears to be the main tool to improve this dimension, as well as initiatives to retain creative profiles.

- Smart Living (social equity): Efficient management of urban facilities (e.g., cultural, recreation), public spaces, and services (e.g., healthcare, education) using ICT technologies to improve accessibility, flexibility of use, and to meet citizens' needs and eliminate social exclusion. 


\section{Conceptual Assessment Framework}

To achieve the aims of our study, we introduced a framework that allowed us to evaluate the relation between the implementation of smart strategies or solutions and the changes strengthened by the Covid-19 pandemic in five main areas, described in Section 2. The conceptual framework used in this study is based on the findings of the ASCIMER project (Monzon, 2015), which show how urban challenges in European cities can be classified concerning the smart city action fields. The framework was adopted to study how different Covid-19-caused urban trends influence the smart development of the cities. Our model allows us to assess how strategies and solutions concerning different aspects of the smart city idea-governance, economy, mobility, environment, people, and living-may support the positive changes caused by the Covid-19 pandemic on different aspects of city structures. Those changes were assessed in the context of the future renewal of cities, indispensable to support their resilience to other pandemic crises and their response to the challenges of the climate crisis. Due to the fairly short period that has elapsed since the pandemic started, we based our study on short-term changes and interventions. We also tried to predict possible long-term effects of those changes.

Table 1 assesses city transformation trends strengthened by the Covid-19 pandemic (columns) concerning aspects that characterise smart solutions (rows). It was assessed crosswise whether, within a given relationship, the interactions might be strong, moderate, or insignificant. The assessment relies on the above-mentioned phenomena; evidence was gathered in desk research of scientific papers, case studies, published policy reports, and own observations from planning practice. A strong relation $(++)$ is supported by both empirical research of case studies and policy implementation. A moderate relation $(+)$ represents indirect influence supported by empirical research, with no policy implementation observed on the strategic level. In the case of a lack of defined association, the relationships are omitted (-).

\subsection{Influence of City Structure on Development Changes in the Smart City}

The research conducted in Guadalajara since 2009 (AH1N1 influenza pandemic) and on theoretical models has shown that the reduction of interactions between residents of distant neighbourhoods travelling to the centre (or other work areas) has a vital importance for reducing the spread of the pathogens (Brizuela et al., 2021). The study also indicated a need for an in-depth analysis of mobility patterns, which is crucial in shaping spatial connections. It also showed that city spatial structures based on mono functionality and separation lead to a faster spread of pathogens than the model based on dispersed areas of human activity. Research conducted in Madrid (Menéndez \& Higueras García, 2020) and Porto (da Silva Lopes et al., 2021) during the Covid-19 pandemic has shown an accelerated loss of traditional service functions by city centres, especially those targeting global tourism. These studies highlighted the need to deepen the analysis in the context of the polycentric development of urban structures.

According to an IPC Research Institute (Wrocław, Poland) report based on statistics, the number of people working remotely in their place of residence increased by about $60 \%$ in the first months of the pandemic (KPMG, 2020; Krysiński, 2020). The popularisation of remote work resulted in the reduction of demand for office space. Surveyed companies declare at least partial implementation of the remote-work model on a larger scale than before (Colliers, 2021). In the field of ad hoc measures, initiatives have been taken in many cities to prevent crowded commutes and gatherings in workplaces. The local governments recommended staggered work hours e.g., in the Ile-de-France region (UN, 2020), a charter with businesses, social partners, local governments, and the public transportation sector with suggestions to stagger arrival and departure times in businesses is being negotiated.

It can be noticed that the Covid-19 pandemic has accentuated, among others, the problem of excessive concentration of areas dedicated only to tourism and

Table 1. Impact of the pandemic-caused changes on the development of various aspects of smart cities.

\begin{tabular}{|c|c|c|c|c|c|c|}
\hline & & \multicolumn{5}{|c|}{ City Transformation Trends Strengthened by the Covid-19 Pandemic } \\
\hline & & $\begin{array}{c}\text { City } \\
\text { Structure }\end{array}$ & $\begin{array}{l}\text { Mobility and } \\
\text { Public } \\
\text { Transportation }\end{array}$ & $\begin{array}{l}\text { Shape and } \\
\text { Function of } \\
\text { Public Spaces }\end{array}$ & $\begin{array}{c}\text { Access to Open } \\
\text { Spaces and } \\
\text { Green Areas }\end{array}$ & $\begin{array}{c}\text { Digital } \\
\text { Transformation }\end{array}$ \\
\hline \multirow{6}{*}{ Smart } & Governance & - & - & - & - & ++ \\
\hline & Economy & + & - & - & - & + \\
\hline & Mobility & + & ++ & - & - & + \\
\hline & Environment & - & - & ++ & ++ & + \\
\hline & People & - & + & + & - & ++ \\
\hline & Living & + & - & + & + & + \\
\hline
\end{tabular}


accelerated trends in the implementation of remote work and learning. While distance learning, especially at the primary and secondary levels, seems to be a temporary change, remote work, especially in the service and administration sector, may turn out to be more permanent and more common.

In light of individual smart aspects, it can be assumed that as a result of the pandemic, development strategy models, business models, and adaptation to current changes in the local and global economy (smart economy) will change faster. The second aspect is the interrelated change in lifestyles, ways of travelling, and especially of studying and working, resulting in changes in travel patterns that may be permanently changed (smart mobility and smart living).

\subsection{The Influence of Urban Flows, Connectivity, and Mobility Changes on Smart Cities}

The launch of both remote work and distance learning systems reduced individual road traffic and, at the same time, severe restrictions for public transport passengers were introduced ("Coronavirus: Wuhan shuts public transport over outbreak," 2020; Xu, 2020). According to a report by Moovit (2020), a leading website implementing mobility solutions, in the first months of the pandemic, public transport travel in cities around the world fell drastically-e.g., 86\% in Madrid, 54\% in New York, $24 \%$ in Lyon, $44 \%$ in London, and $30 \%$ in Gdynia, Poland (Management of Roads and Greenery, 2020). As a result of the restrictions, many city dwellers chose alternative ways of getting around, such as shared transport, bicycles, or walking (von Oldershausen, 2020).

Users of most applications admit that they are more likely to walk or cycle now than before the pandemic. The recovery of public transport depends on increasing the frequency of vehicle journeys, the possibility of contactless payment service, and improving the sanitary and hygiene conditions in vehicles, including better air exchange (Moovit, 2020).

Pilot actions in the field of mobility and public transport development have been implemented in many cities as necessary conditions for their efficient functioning. A suitable example of such an approach can be the case of Madrid, where implementation started with simple solutions to reduce direct social contact by providing the majority of trains (64\%) with automatic doors and rearranging bus routes based on the current variations in demand. At the same time, due to the influence of the pandemic on urban supply chains, new innovative solutions have been introduced. Cities adopted various "responsible transport policies," which varied in their approaches and degree (Kim, 2021). Lee and Lee (2020) describe early actions which have been undertaken in cities of South Korea such as drive-thru testing facilities or aggressive contact tracing, as well as the adoption of new technologies like online mapping to track the spreading of the disease.
The cited studies indicate that, in terms of mobility, the changes caused by the current pandemic may affect the transformation of cities in the spirit of smart mobility and smart people, due to the need to adapt public transport to its users, who are now more aware of their needs after the pandemic. The post-pandemic public transport crisis may become an opportunity to create a more sustainable, digitally assisted system based on new customer-oriented technologies (Moovit, 2020).

\subsection{The Influence of Change in Shape and Function Public Spaces on Smart Cities}

Various cities such as Vienna, Boston, Oakland, Philadelphia, and Minneapolis limited space for cars as they wish to give it back to pedestrians and cyclists (Laker, 2020) within the World Health Organization (2021) guidelines on social distancing. These temporary road closures and other short-term measures serve as a testing ground for changes in the public realm that may eventually become permanent (Bliss, 2020; Honey-Rosés et al., in press). In Bogotá, cycle lanes were widened and $76 \mathrm{~km}$ of temporary cycling paths were added. Milan also added $35 \mathrm{~km}$ of cycling paths (Armario, 2020).

In Gdańsk, Poland, Wajdeloty Street was temporarily closed to car traffic, making it available to residents as a promenade with extended restaurant gardens established in recent years in a renewal programme (Portal of the City of Gdańsk, 2020). Prototyping and implementing solutions for the duration of the pandemic can consolidate the use of squares and streets, supporting the process of change in degraded city areas. Recognising the need to maintain physical distance, several initiatives whose goal was to widen sidewalks and separate bicycle paths in existing roadways appeared. These initiatives were described on industry portals or local government websites (Combs, 2020).

In Baltimore, a guide for model solutions for the development of space was created to support interaction between residents on streets, squares, and pavements dedicated to the time of the pandemic. The recommended solutions are universal. Using squares to create a local housing estate centre for organising social activities (childcare, snack food, daily service points, or a library) can be implemented in any city (City of Baltimore, 2020).

Monitoring tools have been implemented on a larger scale in cities. Already in 1975 Foucault indicated that public spaces were being increasingly "panopticonned," i.e., subject to observation and control (Foucault, 1977), but the Covid-19 pandemic sanctioned this situation. For instance, France used CCTV in the Paris metro to estimate the use of facemasks (Honey-Rosés et al., in press). Rapidly developing phone applications for contact tracing started to be widely accepted by the public (French \& Monahan, 2020). One can find more than 50 statedriven tracking applications projects in 30 countries, in addition to the collaboration between Apple and Google (GDPRhub, 2021). It is highly probable that those kinds of 
systems, when fully introduced, will stay with us for a long time. The mentioned examples of research and activities indicate that the pandemic has contributed to a change in the use of public spaces related to the notions of a smart environment. Local and bottom-up initiatives can be considered activities in the spirit of "smart people"communities seeking active measures to improve the quality of life by strengthening social capital, increased control, and narrowing the sphere of privacy.

\subsection{The Influence of Change in Accessibility to Open Spaces and Green Areas on Smart Cities}

With limited access to other recreational areas, the importance of public greenery increased during the pandemic. The research conducted on global, regional, and local scales, based on data from the Google Community Mobility Report (Google, 2021) from the first wave of the pandemic (February through May 2020) points to increased activity in the immediate area of residence up to several dozen percent (Slater et al., 2020). Conclusions from the Oslo research show that densely wooded areas on the outskirts of cities and green areas within residential estates were more willingly used; this study also indicated that residents adhered to physical distancing recommendations by avoiding frequently visited areas (Venter et al., 2020).

Searching for opportunities to enlarge open spaces dedicated to recreation, city residents turned towards less frequented areas, which caused spaces that were previously used passively to become populated (Jakubowski, 2020; The Trust for Public Land, 2020; van den Berg, 2020). The research analysing park visits in 130 countries around the world has shown an increase compared with a baseline from before the outbreak and has associated this phenomenon with the restrictions in the public policies that limited people's social and physical contacts (Geng et al., 2020). These studies, even though they prove similar phenomena, cannot be universal due to various restrictions that were introduced by governments or regions.

As early as April 2020, recommendations for actions to prevent mental and psychological problems in the face of the pandemic, including the need to spend time in the natural environment, were advertised (Mental Health Foundation, 2020). In parks and squares around the world, initiatives were implemented ensuring contact with nature and interaction between people while maintaining the recommended distances (Harrouk, 2020; Union of the Baltic Cities, 2020).

Access to open areas and greenery is one of the smart factors describing the quality of life in the city related to environmental factors (smart environment). Access to green areas is related to the smart living factor through the analytical methods for better planning. The spatial structure of cities can also be planned more effectively if planners think of reusing degraded areas for recreational purposes.

\subsection{The Influence of Digital Transformation on Smart Cities}

Throughout the pandemic, using modern technologies, local communities and spontaneous initiative groups (e.g., in the French cities of Bordeaux and Reims, as well as in Milan) have developed platforms to exchange information based on both existing and newly created social media platforms (EUROCITIES, 2020). Industries with the highest level of remote work managed to maintain their business activity at the level of $70-80 \%$. At the same time, the risk of deepening social and economic inequalities resulting from limited access to Internet networks (both for entire countries and social groups) remains at the same level (OECD, 2020a).

For many municipalities, the pandemic was a strong push towards promoting digital literacy among citizens. A good example is a consultation process for development plans in small Polish municipalities conducted under the project New Quality of Public Consultation. Since March 2020, meetings have been held online while local governments received technical and methodological support for the process. Inviting online participation has become common practice not only in large cities but also in smaller towns and villages. The crisis is pushing many cities to accelerate their pursuit of digital solutions not only during lockdowns but also in the long-term as part of their participatory processes. Cities like Antwerp, Cologne, and Madrid launched calls for start-ups to create innovative new ways to overcome challenges related to Covid-19 (OECD, 2020b).

The transfer of many spheres of public, cultural, and professional life into virtual space may constitute both an opportunity and a threat to the functioning of an urban society, in terms of work and distance learning. Al was considered as part of the solution to be implemented during lockdowns (Kritikos, 2020). As a result, Al-based fever detection systems and processing data to track a person's recent movements were introduced. Hantrais et al. (2020) point out, however, that the massive use of Al tracking and surveillance tools used since the outbreak of Covid-19, combined with fragmentation in the ethical governance of Al, might have paved the way for extended and more permanent use of surveillance technologies to justify personal freedom.

The Covid-19 pandemic accelerated and extended digital transformation in many areas. It affected the direction and speed of development of digital technologies such as the internet, mobile connectivity, cloud computing, big data, machine learning, Al, blockchain, loT, smart manufacturing, and predictive and data analytics (Soto-Acosta, 2020). Due to their embeddedness in urban space, they need to be considered alongside the development of key conceptual components of the smart city. Utilising those technologies can give a strong push in the direction of predictive data analytics and allow progress towards data-driven urban planning and real-time urban management. Remote work and digitally 
organised logistics have played a key role in mitigating the impacts of the pandemic; moreover, with significant resulting benefits, these trends are likely to be expanded during the post-Covid-19 recovery (Oldekop et al., 2020). Tokyo is now committed to accelerating its efforts towards a digital transformation. It promotes online learning, telemedicine, telecommuting, and the digitalisation of public services (OECD, 2020a). Madrid defines its Covid-19 recovery plans concerning the participatory processes aiming to find solutions to three challenges: facing the economic reality after the pandemic; redefining the concept of cities in the face of the need for new models of interpersonal relationships; and seeking solutions for groups with special needs (EUROCITIES, 2020).

\subsection{Policy Implications}

In accordance with the methodology applied here, global (or universal) and local dependencies could be distinguished. The first category includes reference materials published by the World Health Organization and systematically updated based on research, such as the guidelines for the physical distance (World Health Organization, 2021), which have significant consequences in various spheres, including cities. The UN (2020) published a report where it referred to urbanised areas. It contains recommendations for the renewal of cities after the pandemic crisis, postulating, inter alia, a strengthening of data-driven planning. The report emphasises the experience of the pandemic, and the possibility to improve air quality in cities (due to reduction in transport). It also highlights the roles of credible and solid research that allows national and local authorities to better respond to the crisis and points out that the future of urban planning and management should follow a similar pattern. Analogous recommendations were presented in the UN-Habitat document (UN-Habitat, 2020), which indicates pandemic management support tools that may be used in the future for data mapping. It proves the impact of the pandemic as a catalyst for change towards the development of the smart city model on a global scale. Data-driven planning can improve the quality of land management in light of urban regeneration and the building of resilient cities. Changes in that sphere will require new mechanisms or legal frameworks but also develop strategies and may be seen in a long-term perspective, as the pandemic did not damage urban structures.

In the "new normality," certain spatial consequences will inevitably result from the change in the residents' lifestyles. A flexible approach to the workplace may increase the interest in rental offers of smaller offices or co-working spaces, enabling greater adaptability to current needs. Both factors can contribute to the revival of services in the form of high-street or local service centres accessible on foot. The pandemic influenced the creation of sectoral policies, such as mobility in the analysed context (especially public transport). The International Association of Public Transport, publishing publicly available reports and research results, promotes a return to public transport as well as the digital transformation of "smart working practices." The new mobility model can help to reduce emissions, improve air quality, and support attempts at reducing crowds in public transport.

\section{Discussion}

The analysed studies, policies, and projects suggest that the experience of the effects of the pandemic might bring about significant changes in the future of cities. The recent pandemic has accelerated the smart development of urban structures and the implementation of smart solutions. Many urban areas require a transformation to solve the structural problems of their built environment. The pandemic-caused changes confirm that areas with diversified functions, mainly residential areas with good access to services, are more resilient in case of a disaster. There is a need to strengthen this aspect of city planning, especially in the face of the announcements by service providers and employers, who are going to promote remote work in the future.

Our studies have shown that the Covid-19 pandemic can become a catalyst of urban change. The multifunctional city structure based on local service centres can contribute to a transformation of the city towards a more resilient and safer environment. There is a significant challenge to meet social expectations regarding public transport. Restoring its patronage to pre-pandemic numbers will require a reorganisation of routes and timetables, but also the implementation of solutions that guarantee safety, such as the non-contact operation or efficient ventilation systems in vehicles. The main threat to this approach is the trend to use individual cars, perceived as a safer form of mobility. However, maintaining a larger share of bicycle traffic by ensuring an efficient network of safe connections and transforming temporary connections into permanent ones may have a beneficial effect, too. Also, streets, sidewalks, and squares "regained" by residents during the pandemic stand a chance of permanent transformation, especially in places where they may be associated with ground-floor services. In revitalised or degraded areas, high-quality public space is an element of the strategy to change their image. Mobility restrictions highlighted the problem of limited access to open and natural areas. The need to keep physical distance prompted city residents to explore less obvious walking routes. These places, restored to public awareness, can become the target of future local initiatives.

The pandemic may also be the catalyst for changes towards Smart City 3.0 and smart solutions support the positive direction of those changes. The examples of spatial changes introduced above, although forced by the pandemic, were adopted by cities and their residents. They represent a great potential for the implementation 
of the Smart City 3.0 model defined by Cohen (2014). A smart city is not only a digital city but, above all, a city that answers the needs of its residents. During the pandemic, faster implementation and acceptance of digital innovative solutions have been observed, which, together with their larger inclusiveness, can be a test of their embeddedness in urban space.

Smart cities aim to apply digital technologies to advance the well-being of their citizens, although there are cities that are merely "smart washing" and adopt superficial technological solutions that chase the symptoms rather than causes of complex urban problems (Anand, 2021; Hantrais et al., 2020). The outbreak of the pandemic confirmed pre-Covid-19 findings that cities with robust governance and participation mechanisms were likely to be resilient and manage crises considerably better than those "using isomorphic mimicry to look like a smart city" (Hantrais et al., 2020, p. 263; OECD, 2020a).

The framework introduced in this study identifies those aspects of smart cities that were to the greatest extent influenced by the Covid-19 pandemic. Indicating connections between smartness and postCovid-19 urban trends, this study can form a base for future comparative studies showing regional specificities, as trends, as well as solutions and planning practices, are not homogeneous between cities and regions. This study has identified a variety of direct responses to pandemics as well as the diversity of directions of future spatial development policies vectored by the urban changes caused by Covid-19.

As this study was conducted during the lockdown, it is partly empirical in nature. For that reason, it would be worth conducting an ex-post evaluation which could allow for a more rigorous scientific process based on both qualitative and quantitative indicators. The pandemic has also increased our understanding of the importance of the well-being and mental health of city residents and of how they may impact their relationship with smart city services (Coca-Stefaniak, 2020). Future studies might therefore focus on factors for providing a more intuitive relationship between smart cities and their residents and visitors alike by developing further the predictive elements of smart services. Another vital aspect is the influence of such phenomena as the pandemic on the resilience of urban structures. Our studies show that it can be both stimulating for some urban changes (such as the increase of active mobility, namely the share of bike trips in mobile-splits of the cities), but, at the same time, quite impeding for others (see the turn from public transport towards individual cars, which were perceived as a safer means of transportation).

\section{Conclusions}

The pandemic has continued with varying gravity for several months and it is hard to predict when it will end. Although extensive multi-threaded studies and analyses of its influence on cities together with the practical expe- rience of local governments and residents are being gathered, the question about how the pandemic will affect cities and influence the implementation of intelligent solutions remains open. The experience of the global crisis will remain a reference point for shaping new guidelines or practices, the more so as the pandemic has not eliminated threats related to climate change and challenges city residents faced before 2020. Whether the current spontaneous changes will become permanent depends on the duration of the pandemic. The longer the "state of emergency" lasts, the more all-embracing changes in the structure of cities and their management will occur. In discussions about the city after the pandemic, two notions appear: "new normality," describing the current state of uncertainty, and the more optimistic one, "new future" (World Health Organization, 2020). Among the visions of the post-pandemic world, we can find dystopian ideas caused by fear of crowding, reduced sense of security, limited job opportunities, access to services, culture, and art, and, above all, by reduced social interactions. At the same time, urban researchers indicate that similar crises in the past strengthened cities and the present one may additionally contribute to the transformation of current cities into cities that are more resilient and more efficiently adapt to contemporary challenges including climate change (Florida, 2020). The experience of the pandemic can accelerate spatial changes both in terms of short-term actions and long-term development policies. Short-term activities in degraded areas can improve the structure and functioning of cities through the introduction of spontaneous and temporary solutions. The faster pace of digitisation in areas such as transport or education will affect the functioning of cities. Within public space, one should expect a change resulting from the experience of physical distancing. Long-term effects relate to the development policies of entire urban areas, as their strengths and weaknesses have been highlighted by the pandemic. The notions of the "new normal" and the "new future" are an opportunity to redefine development policies that fit within the idea of smart, resilient, and sustainable cities.

\section{Acknowledgments}

The authors are grateful for the exceptionally valuable comments from the reviewers and editors.

\section{Conflict of Interests}

The authors declare no conflict of interests.

\section{References}

Anand, P. B. (2021). Assessing smart city projects and their implications for public policy in the Global South. Contemporary Social Science, 16(2), 199-212.

Angelidou, M. (2014). Smart city policies: A spatial approach. Cities, 41, 3-11. 
Armario, C. (2020, March 17). Bogotá fomenta uso de bicicletas para prevenir Covid-19 [Bogotá encourages bicycle use to prevent Covid-19]. San Diego Union-Tribune en Español. https://www.sandiego uniontribune.com/en-espanol/noticias/story/202003-17/bogota-fomenta-uso-de-bicicletas-paraprevenir-covid-19

Bereitschaft, B., \& Scheller, D. (2020). How might the Covid-19 pandemic affect 21st century urban design, planning, and development? Urban Science, 4(4), Article 56. https://doi.org/10.3390/urbansci 4040056

Berry, C. R., \& Glaeser, E. L. (2005). The divergence of human capital levels across cities. Papers in Regional Science, 84(3), 407-444.

Bliss, L. (2020). Mapping how cities are reclaiming street space. Bloomberg CityLab. https://www.bloomberg. com/news/articles/2020-04-03/how-coronavirus-isreshaping-city-streets

Boes, K., Buhalis, D., \& Inversini, A. (2016). Smart tourism destinations: Ecosystems for tourism destination competitiveness. International Journal of Tourism Cities, 2(2), 108-124. https://doi.org/10.1108/IJTC12-2015-0032

Bosch, P., Jongeneel, S., Rovers, V., Neumann, H.-M., Airaksinen, M., \& Huovila, A. (2017). CITYkeys indicators for smart city projects and smart cities. CITYkeys. https://nws.eurocities.eu/MediaShell/media/ CITYkeystheindicators.pdf

British History Online. (2019). Charles II, 1666: An Act for rebuilding the Citty of London. https://www.britishhistory.ac.uk/statutes-realm/vol5/pp603-612

Brizuela, N. G., García-Chan, N., Gutiérrez Pulido, H., \& Chowell, G. (2021). Understanding the role of urban design in disease spreading. Proceedings of the Royal Society A: Mathematical, Physical and Engineering Sciences, 477(2245), Article 20200524. https://doi. org/10.1098/rspa.2020.0524

Caragliu, A., Del Bo, C., \& Nijkamp, P. (2011). Smart cities in Europe. Journal of Urban Technology, 18(2), 65-82.

Chourabi, H., Nam, T., Walker, S., Gil-Garcia, J. R., Mellouli, S., Nahon, K., Pardo, T. A., \& Scholl, H. J. (2012). Understanding smart cities: An integrative framework. In Proceedings of the forty-fifth annual Hawaii International Conference on System Sciences (pp. 2289-2297). IEEE.

City of Baltimore. (2020). Design for distancing. https:// www.designfordistancing.org

Coca-Stefaniak, J. A. (2019). Marketing smart tourism cities-A strategic dilemma. International Journal of Tourism Cities, 5(4), 513-518. https://doi.org/ 10.1108/IJTC-12-2019-163

Coca-Stefaniak, J. A. (2020). Beyond smart tourism cities-Towards a new generation of "wise" tourism destinations. Journal of Tourism Futures, 7(2), 251-258. https://doi.org/10.1108/JTF-11-20190130
Coe, A., Paquet, G., \& Roy, J. (2001). E-Governance and smart communities: A social learning challenge. Social Science Computer Review, 19(1), 80-93.

Cohen, B. (2014). The smartest cities in the world 2015: Methodology. Fast Company. https://www. fastcompany.com/3038818/the-smartest-cities-inthe-world-2015-methodology

Colliers. (2021). Rynek biurowy. Polska. Raport Roczny rozszerzony [Office market. Poland. Annual extended report]. http://docs.colliers.pl/reports/Rynekbiurowy_Rozszerzony-Raport-Roczny-2021.pdf

Combs, T. (2020). Local actions to support walking and cycling during social distancing dataset [Data set]. Pedestrian and Bicycle Information Centre. http://pedbikeinfo.org/resources/resources_details. cfm?id=5209

Coronavirus: Wuhan shuts public transport over outbreak. (2020, January 23). BBC News. https://www. bbc.com/news/world-asia-china-51215348

da Silva Lopes, H., Remoaldo, P. C., Ribeiro, V., \& MartínVide, J. (2021). Effects of the Covid-19 pandemic on tourist risk perceptions-The case study of Porto. Sustainability, 13(11), Article 6399. https://doi.org/ 10.3390/su13116399

de Valderrama, N. M.-F., Luque-Valdivia, J., \& Aseguinolaza-Braga, I. (2020). La ciudad del cuarto de hora, ¿una solución sostenible para la ciudad post-Covid-19? [The 15-minutes city, a sustainable solution for post-Covid-19 cities?]. Ciudad y Territorio Estudios Territoriales, 52(205), 653-664. https://doi.org/10.37230/cytet.2020.205.13.1

Diao, M. (2019). Towards sustainable urban transport in Singapore: Policy instruments and mobility trends. Transport Policy, 81, 320-330. https://doi.org/ 10.1016/j.tranpol.2018.05.005

Dietz, L., Horve, P. F., Coil, D. A., Fretz, M., Eisen, J. A., \& Van Den Wymelenberg, K. (2020). 2019 novel coronavirus (Covid-19) pandemic: Built environment considerations to reduce transmission. mSystems, 5(2), Article e00245-20. https://doi.org/10.1128/ mSystems.00245-20

Eubank, S., Guclu, H., Anil Kumar, V. S., Marathe, M. V., Srinivasan, A., Toroczkai, Z., \& Wang, N. (2004). Modelling disease outbreaks in realistic urban social networks. Nature, 429(6988), 180-184. https://doi.org/ 10.1038 /nature02541

EUROCITIES. (2020, July 1). Preliminary overview of city measures to mitigate the socioeconomic impact of Covid-19 [Policy note]. https://nws.eurocities.eu/ MediaShell/media/Overview_of_city_measures_to_ mitigate_the_socio-economic_impact_of_cOVID19_updated_1_July.pdf

Florida, R. (2020). The lasting normal for the postpandemic city. Bloomberg CityLab. https://www. bloomberg.com/news/features/2020-06-25/thenew-normal-after-the-coronavirus-pandemic

Foucault, M. (1977). Discipline and punish: The birth of the prison. Pantheon Books. 
Frank, L. D. (1994). Impacts of mixed used and density on utilization of three modes of travel: Single-occupant vehicle, transit, walking. Transportation Research Record Journal of the Transportation Research Board, 1466, 44-52.

French, M., \& Monahan, T. (2020). Dis-Ease surveillance: How might surveillance studies address Covid-19? Surveillance \& Society, 18(1), 1-11. https://doi.org/ $10.24908 /$ ss.v18i1.13985

Fuller, R. A., \& Gaston, K. J. (2009). The scaling of green space coverage in European cities. Biology Letters, 5(3), 352-355. https://doi.org/10.1098/rsbl. 2009.0010

GDPRhub. (2021). Data protection under SARS-CoV-2. https://gdprhub.eu/index.php?title=Data_ Protection_under_SARS-CoV-2

Gehl, J. (2007). Public spaces for a changing public life. In C. W. Thompson \& P. Travlou (Eds.), Open space: People space (pp. 23-30). Routledge.

Geng, D., Innes, J., Wu, W., \& Wang, G. (2020). Impacts of Covid-19 pandemic on urban park visitation: A global analysis. Journal of Forestry Research, 32, 553-567. https://doi.org/10.1007/s11676-020-01249-w

Google. (2021). Covid-19 community mobility reports. https://www.google.com/covid19/mobility

Graells-Garrido, E., Serra-Burriel, F., Rowe, F., Cucchietti, F. M., \& Reyes, P. (2021). A city of cities: Measuring how 15 -minutes urban accessibility shapes human mobility in Barcelona. PLOS ONE, 16(5), Article e0250080. https://doi.org/10.1371/journal.pone. 0250080

Griffinger, R., Fertner, C., Kramar, H., Kalasek, R., PichlerMilanovic, N., \& Meijers, E. (2007). Smart citiesRanking of European medium-sized cities. Vienna University of Technology.

Gwiazdzinski, L. (2015, July 27-28). Space-time design for chrono-urbanism in smart city [Conference paper]. ICSSC 2015-3rd International Conference on Smart Sustainable City and Big Data, Shanghai, China.

Hantrais, L., Allin, P., Kritikos, M., Sogomonjan, M., Anand, P., Livingstone, S., Williams, M., \& Innes, M. (2020). Covid-19 and the digital revolution. Contemporary Social Science, 16(2), 1-15.

Harrouk, C. (2020). Domino Park introduces social distancing circles to adapt to the Covid-19 crisis. ArchDaily. https://www.archdaily.com/940244/dominopark-introduces-social-distancing-circles-to-adaptto-the-covid-19-crisis

Honey-Rosés, J., Anguelovski, I., Chireh, V. K., Daher, C., Konijnendijk van den Bosch, C., Litt, J. S., Mawani, V., McCall, M. K., Orellana, A., Oscilowicz, E., Sánchez, U., Senbel, M., Tan, X., Villagomez, E., Zapata, O., \& Nieuwenhuijsen, M. J. (in press). The impact of COVID-19 on public space: An early review of the emerging questions-Design, perceptions and inequities. Cities \& Health. https://doi.org/10.1080/ 23748834.2020.1780074

International Organization for Standardization. (2014).
ISO 37120:2014. Sustainable development of communities - Indicators for city services and quality of life. https://www.iso.org/standard/62436.html

ITU-T Focus Group on Smart Sustainable Cities. (2015). Key performance indicators definitions for smart sustainable cities (Focus Group Technical Report). International Telecommunication Union.

Jakubowski, K. (2020). Czwarta przyroda w mieście. Autoportret [The fourth nature in the city. Self-portrait]. Małopolska Institute of Culture in Kraków. https:// autoportret.pl/artykuly/czwarta-przyroda-w-miescie

Kabisch, N., \& Haase, D. (2014). Green justice or just green? Provision of urban green spaces in Berlin, Germany. Landscape and Urban Planning, 122, 129-139. https://doi.org/10.1016/j.landurbplan.2013.11.016

Keeling, M. J. (1999). The effects of local spatial structure on epidemiological invasions. Proceedings of the Royal Society of London. Series B: Biological Sciences, 266(1421), 859-867. https://doi.org/10.1098/ rspb.1999.0716

Kim, K. (2021). Impacts of Covid-19 on transportation: Summary and synthesis of interdisciplinary research. Transportation Research Interdisciplinary Perspectives, 9, Article 100305. https://doi.org/10.1016/ j.trip.2021.100305

Komninos, N. (2011). Intelligent cities: Variable geometries of spatial intelligence. Intelligent Buildings International, 3(3), 172-188. https://doi.org/10.1080/ 17508975.2011 .579339

Kourtit, K., \& Nijkamp, P. (2013). In search of creative champions in high-tech spaces: A spatial application of strategic performance management. Journal of Regional Science, 53(5), 749-777.

KPMG. (2020). Automotive's new reality: Fewer trips, fewer miles, fewer cars? https://advisory.kpmg.us/ content/dam/advisory/en/pdfs/2020/automotivesnew-reality.pdf

Kritikos, M. (2020). What if we could fight coronavirus with artificial intelligence? European Parliamentary Research Service. https://www.europarl.europa.eu/ RegData/etudes/ATAG/2020/641538/EPRS_ ATA(2020)641538_EN.pdf

Krysiński, D. (2020). Raport z możliwości zastosowania pracy zdalnej $w$ przedsiębiorstwach $i$ instytucjach publicznych [Report on the possibility of using remote work in enterprises and public institutions]. Instytut Badawczy IPC, Openfield, and EDBAD. http://www.dwup.pl/asset/images/files/Raport_ 20201016.pdf

Laker, L. (2020, April 11). World cities turn their streets over to walkers and cyclists. The Guardian. https://www.theguardian.com/world/2020/apr/ 11/world-cities-turn-their-streets-over-to-walkersand-cyclists

Lee, D., \& Lee, J. (2020). Testing on the move: South Korea's rapid response to the Covid-19 pandemic. Transportation Research Interdisciplinary Perspectives, 5, Article 100111. 
Maas, W. (2003). Five minutes city: Architecture and (im)mobility. Episode Publishers.

Management of Roads and Greenery. (2020). Ruch na Gdyńskich drogach w czasie pandemii [Traffic on Gdynia roads during the pandemic]. https://www.zdiz. gdynia.pl/ruch-na-gdynskich-drogach-w-czasiepandemii

Menéndez, E. P., \& Higueras García, E. (2020). Urban sustainability versus the impact of Covid-19. DisPThe Planning Review, 56(4), 64-81. https://doi.org/ 10.1080/02513625.2020.1906059

Mental Health Foundation. (2020). Mental health in the Covid-19 pandemic: Recommendations for prevention. https://www.mentalhealth.org.uk/sites/ default/files/MHF\%20Mental\%20Health\%20in\% 20the\%20COVID-19\%20Pandemic.pdf

Monzon, A. (2015). Smart cities concept and challenges: Bases for the assessment of smart city projects. In M. Helfert, K.-H. Krempels, C. Klein, B. Donellan, \& O. Guiskhin (Eds.), Smart cities, green technologies, and intelligent transport systems (pp. 17-31). Springer.

Moovit. (2020). The Covid-19 effect: How is urban mobility evolving across the world? https://moovit. com/resources/ebooks-and-infographics/the-covid19-effect-how-is-urban-mobility-evolving-acrossthe-world

Murgante, B., \& Borruso, G. (2015). Smart cities in a smart world. In S. T. Rassia \& P. M. Pardalos (Eds.), Future city architecture for optimal living (pp. 13-35). Springer.

Nakamura, K., \& Hayashi, Y. (2013). Strategies and instruments for low-carbon urban transport: An international review on trends and effects. Transport Policy, 29, 264-274. https://doi.org/10.1016/j.tranpol. 2012.07.003

Naphy, W., \& Spicer, A. (2004). Czarna śmierć [Black death]. Państowy Instytut Wydawniczy.

Neirotti, P., De Marco, A., Cagliano, A. C., Mangano, G., \& Scorrano, F. (2014). Current trends in smart city initiatives: Some stylised facts. Cities, 38, 25-36. https:// doi.org/10.1016/j.cities.2013.12.010

Nicola, M., Alsafi, Z., Sohrabi, C., Kerwan, A., Al-Jabir, A., losifidis, C., \& Agha, M. (2020). The socioeconomic implications of the coronavirus pandemic (Covid-19): A review. International Journal of Surgery, 78, 185-193.

OECD. (2020a). Digital transformation in the age of Covid-19: Building resilience and bridging divides (Digital economy outlook 2020 supplement). www. oecd.org/digital/digital-economy-outlook-covid.pdf

OECD. (2020b). OECD policy responses to Coronavirus (Covid-19): Cities policy responses. https:// read.oecd-ilibrary.org/view/?ref=126_126769yen45847kf\&title=Coronavirus-COVID-19-CitiesPolicy-Responses\&_ga=2.189576680.2118078399. 1633945582-424570284.1633945580

Oldekop, J. A., Horner, R., Hulme, D., Adhikari, R., Agarwal, B., Alford, M., Bakewell, O., Banks, N., Barrientos,
S., Bastia, T., Bebbington, A. J., Das, U., Dimova, R., Duncombe, R., Enns, C., Fielding, D., Foster, C., Foster, T., Frederiksen, T., \& Gao, P. (2020). Covid-19 and the case for global development. World Development, 134, Article 105044. https://doi.org/10.1016/ j.worlddev.2020.105044

Parimala, M., \& Lopez, D. (2016). Spatio-temporal modelling of frequent human mobility pattern to analyse the dynamics of epidemic disease. International Journal of Intelligent Engineering and Systems, 9(4), 167-178. https://doi.org/10.22266/ijies2016. 1231.18

Portal of the City of Gdańsk. (2020). Wrzeszcz Dolny. Nowa inicjatywa: do niedzieli ulica Wajdeloty jest deptakiem [Wrzeszcz Dolny. New initiative: Until Sunday, Wajdeloty Street is a pedestrian zone]. https://www.gdansk.pl/wiadomosci/na-dlugiweekend-od-11-do-14-czerwca-ulica-wajdelotystanie-sie-deptakiem, a, 172413

Slater, S. J., Christiana, R. W., \& Gustat, J. (2020). Recommendations for keeping parks and green space accessible for mental and physical health during Covid-19 and other pandemics. Preventing Chronic Disease, 17, Article 200204. https://doi.org/10.5888/pcd17. 200204

Smith, T. E., \& Zenou, Y. (2003). Spatial mismatch, search effort, and urban spatial structure. Journal of Urban Economics, 54(1), 129-156. https://doi.org/10.1016/ s0094-1190(03)00040-8

Soto-Acosta, P. (2020). Covid-19 pandemic: Shifting digital transformation to a high-speed gear. Information Systems Management, 37(4), 1-7. https://doi.org/ 10.1080/10580530.2020.1814461

Stevens, Q. (2007). The ludic city: Exploring the potential of public spaces. Routledge.

The Trust for Public Land. (2020). A Trust For Public Land special report: Parks and the pandemic. https:// www.tpl.org/sites/default/files/Parks\%20and\% 20Pandemic\%20-\%20TPL\%20special\%20report.pdf

UN. (2020). Policy brief: Covid-19 in an urban world. https://www.un.org/sites/un2.un.org/files/sg_ policy_brief_covid_urban_world_july_2020.pdf

UNECE Committee on Housing and Land Management. (2015). The UNECE-ITU smart sustainable cities indicators (ECE/HBP/2015/4). https://unece. org/fileadmin/DAM/hlm/projects/SMART_CITIES/ ECE_HBP_2015_4.pdf

UN-Habitat. (2020). Covid-19 response: Report of activities. https://unhabitat.org/sites/default/files/2020/ 10/covid-19_response_report_web26.10.20.pdf

Union of the Baltic Cities. (2020). Elblag: Social distancing lawn brings people together. https://www.ubc. net/content/elblag-social-distancing-lawn-bringspeople-together

van den Berg, R. (2020, April 10). How will Covid-19 affect urban planning? TheCityFix. https://thecityfix. com/blog/will-covid-19-affect-urban-planningrogier-van-den-berg 
Venter, Z. S., Barton, D. N., Gundersen, V., Figari, H., \& Nowell, M. (2020). Urban nature in a time of crisis: Recreational use of green space increases during the Covid-19 outbreak in Oslo, Norway. Environmental Research Letters, 15(10), Article 104075. https://doi. org/10.1088/1748-9326/abb396

von Oldershausen, S. (2020, July 3). Could New York finally become a bike city? The New York Times. https://www.nytimes.com/2020/07/03/nyregion/ coronavirus-nyc-bike-paths.html?searchResult Position=3

World Health Organization. (2020). From the "new normal" to a "new future": A sustainable response to Covid-19. https://www.who.int/westernpacific/ news/commentaries/detail-hq/from-the-newnormal-to-a-new-future-a-sustainable-response- to-covid-19

World Health Organization. (2021). Advice for the public: Coronavirus disease (Covid-19). https://www. who.int/emergencies/diseases/novel-coronavirus2019/advice-for-public

$\mathrm{Xu}, \mathrm{Y}$. (2020). Public transport in Wuhan suspended due to Coronavirus concerns. NPR. https://www. npr.org/sections/goatsandsoda/2020/01/22/ $798602296 /$ public-transport-in-wuhan-suspendeddue-to-coronavirus-concerns

Yuwen, L., Guofang, Z., Shutian, Z., \& Yijun, S. (2020). Risk reduction through urban spatial resilience: $A$ theoretical framework. Human and Ecological Risk Assessment: An International Journal, 27(2), 1-17. https:// doi.org/10.1080/10807039.2020.1788918

\section{About the Authors}
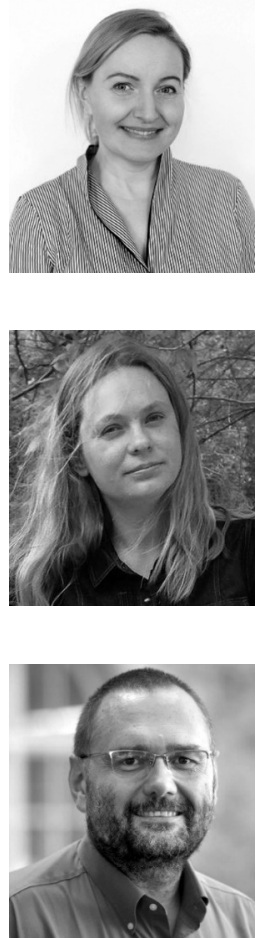

Barbara Zgórska, MArch, MSc, Eng, is a PhD student at the Department of Urban Design and Regional Planning at Faculty of Architecture, Gdańsk University of Technology. She is also a charted urban planner with 16 years of experience working for both the private and public sector, and urban planning expert of the Foundation in Support of Local Democracy in Poland, since 2016. She is also an urban activist, whose main research interests are issues related to urban regeneration and involvement of local communities in city planning processes.

Dorota Kamrowska-Załuska, PhD, is an assistant professor of the Department of Urban Design and Regional Planning at the Faculty of Architecture, Gdańsk University of Technology. She is also a research fellow at several research institutions, including MIT. She has been working as an urban planner for 18 years, for both the private and public sectors. Her research interests are big data and $\mathrm{Al}$ in planning, smart cities, and development of metropolitan areas. She is the author of more than 50 papers and a book on sustainable urban regeneration and the president of the Association of Polish City Planners, Gdańsk division.

Piotr Lorens, PhD, is an urban planner, Gdańsk City architect (since 2021), lecturer in Urban Design and Development, and, since 2007, head of the Department of Urban Design and Regional Planning at the Faculty of Architecture, Gdańsk University of Technology. His research interests and professional practice include planning and implementation of urban development and redevelopment schemes of different nature, varying from decayed urban sites to entire metropolitan areas. 